\title{
EFFECTS OF THE USE OF MIG3 BIOCERAMICS FABRICS USE - LONG INFRARED EMITTER - IN PAIN, INTOLERANCE TO COLD AND PERIODIC LIMB MOVEMENTS IN POST-POLIO SYNDROME
}

\author{
Tatiana Mesquita e Silva', Gustavo Antonio Moreira², Abrahão Augusto Juviniano Quadros?', \\ Márcia Pradella-Hallinan², Sergio Tufik², Acary Souza Bulle Oliveira²
}

\begin{abstract}
The main post-polio syndrome (PPS) symptoms are new-onset weakness, new-onset atrophy, fatigue, cold intolerance, and pain associated with sleep disturbances. The polysomnographic study is the gold pattern to analyze sleep disorders. Objective: To assess pain, intolerance to cold and periodic limb movements (PLM) index before and after the use of MIG3 bioceramic fabrics over 4 weeks. Method: 12 patients with PPS from UNIFESP/EPM. All patients were submitted to polysomnography and infra-red examinations with answered scales of pain and intolerance to cold before and after the use of MIG3 bioceramics fabrics. Results: There were significant decreases in pain and PLM index. Conclusion: MIG3 bioceramic fabrics can help in the treatment of pain and PLM in PPS patients.
\end{abstract}

KEY WORDS: sleep, pain, post-polio syndrome.

Efeitos do uso de tecidos com biocerâmica MIG3 - emissora de infravermelho longo - na dor, intolerância ao frio e movimentos periódicos dos membros na síndrome pós-poliomielite

Resumo - Dentre as manifestações clínicas da SPP destacam-se nova fraqueza, fadiga, dor, intolerância ao frio, nova atrofia e transtornos do sono. A polissonografia de noite inteira permanece sendo padrão ouro para análise do sono e diagnóstico de transtornos do sono. Objetivo: Avaliar o comportamento da dor, intolerância ao frio (IF) e índice de movimentos periódicos de membros (PLMs) após uso de colchonete e roupas com biocerâmica MIG3 por 4 semanas. Método: 12 pacientes com SPP, da UNIFESP/EPM. Todos realizaram exames de polissonografia e infravermelho e responderam a questionários de dor e IF antes e após o uso dos materiais. Resultados: Houve diminuição significativa da dor e dos PLMs. Conclusão: Os tecidos com biocerâmica MIG3 podem ser um coadjuvante ao tratamento da dor e dos PLMs nos pacientes com SPP.

PALAVRAS-CHAVE: sono, dor, síndrome pós-poliomielite.

Poliomyelitis is a viral disease that is typically present during the biphasic phase, with headache, fever and gastrointestinal symptoms, followed days later by impairment of the motor neurons of the spinal cord, which may lead to paralysis, usually involving lower limbs in an asymmetrical and non-proportional way'. Post-polio syndrome (PPS) is characterized by the development of new neuromuscular symptoms that occur after a stability of at least 15 years in patients with previous acute polio paralysis. These symptoms include: (1) new onset of muscular weak- ness and new onset of limb and bulbar or respiratory muscular atrophy [post-polio muscular atrophy (PPMA)], and (2) excessive fatigue and diminished physical resistance. Besides these symptoms, joint and muscle pain, intolerance to cold and sleep disturbances (obstructive and central apneas, periodic limb movements - PLM) frequently occur. PPS is a clinical diagnosis that requires exclusion of other clinical, neurological, orthopedic or psychiatric illnesses that could account for the new symptoms². PPS is a slowly progressive phenomenon, with a stability pe-

Universidade Federal de São Paulo (UNIFESP-EPM) [Federal University of São Paulo], São Paulo SP, Instituto do Sono [Sleep Institute], São Paulo SP, Brazil: ${ }^{1}$ Master in Health Sciences; ${ }^{2} \mathrm{MD}$, PhD.

Received 6 May 2009, received in final form 5 August 2009. Accepted 6 August 2009.

Dra. Tatiana Mesquita e Silva - Av. Rebouças 1278 / 1002 - 05402-000 São Paulo SP - Brasil. E-mail: tatimsilva@gmail.com 
riod higher than 15 years, which may represent up to $70 \%$ of acute paralytic polio survivors ${ }^{3-5}$. Sleep disturbances have been described alongside PPS for decades. Usually, periodic limb movements occur during the first hours of sleep. The movements include feet dorsal flexure and triple flexion of lower limbs ${ }^{6,7}$. Patients who experience PLM report paresthesias from calves to thighs, with arms being rarely involved. The symptoms are usually symmetrically and bilaterally reported. This feeling can be felt inside the leg and can be described as sliding, dragging, discomfort, restlessness or nervousness ${ }^{7,8}$. The patient may present a long asymptomatic period. Depression and sleep disturbances are resulting elements ${ }^{7-9}$. The prevalence in the general population is around $5 \%$. Period limb movements during sleep are an independent nosological entity. These episodes occur more frequently in the first half of the night and provoke arousals from sleep. They lead to sleep fragmentation, unrefreshed sleep and daytime hyper somnolence ${ }^{8,10}$.

In the healthcare field, the effects of luminous radiation on the tissues are well known. Through the action of visible (red) or invisible (infrared) light, luminous radiation promotes a molecular vibration, leading to an increase in the tissue metabolism, called biostimulation. Radiation acts by increasing the cell membrane permeability, favoring the exchange of metabolites as extracellular medium, and by nurturing the cells. It acts on the mitochondria, favoring the ATP synthesis and, consequently, stimulating the synthesis of proteins such as collagen and elastin. It also enhances cell division. In order to provoke this increase in metabolism, the extracellular medium is required to be healthy. Infrared stimulates chemical mediators and hormones that will act on the control of edema, $\mathrm{pH}$, oxygen free radicals and microcirculation, fostering the required conditions for the increase in the cell metabolism ${ }^{11,2}$.

MIG3 bioceramics, an infrared emitter, incorporated in clothes (gloves, shorts, dressings), allows its use at home, in a simple and non-invasive way, at work, and even during sleep, thereby facilitating a patient's daily life. Recent evidence claims that it can control pain, inflammation, accelerate healing in the post-operative period, and minimize the use of drugs and its side effects, through self-regulation mechanism ${ }^{12-16}$.

The objective of this study is evaluate the impact of the use of MIG3 bioceramic over four weeks on pain, intolerance to cold and periodic leg movement in patients with post-polio syndrome.

\section{METHOD}

Twelve patients with post-polio syndrome from the Poliomyelitis and PPS Outpatient Clinic of the Neuromuscular Diseases Department of UNIFESP/EPM (Table 1) were evaluated accord-
Table 1. Demographic data.

\begin{tabular}{lc}
\hline & PPS patients \\
\hline$\#$ & 12 \\
Mean age (years \pm SD) & $46.25 \pm 8.82$ \\
Female gender, $\mathrm{n}(\%)$ & $9(75 \%)$ \\
Ethnia, $\mathrm{n}(\%)$ & \\
$\quad$ White & $9(75 \%)$ \\
Black & $2(16.6 \%)$ \\
Asian & $1(8.4 \%)$ \\
\hline
\end{tabular}

ing to the Mulder post-polio syndrome criteria. These patients were asked to use MIG3 bioceramics fabrics (portable mattress, shirts, dressings and shorts) during 4 weeks.

The polysomnography exam was performed at the beginning of the treatment and soon after its end in our sleep institute.

The infrared exam was performed before the treatment onset and soon after its completion, at the Nove de Julho Hospital, by a specialist in pain diagnostics. In order to perform the exam, patients had to stay in a air conditioned room during $30 \mathrm{~min}$ utes, for stabilization of the body temperature, at $20^{\circ} \mathrm{C}$ and $55 \%$ of air relative humidity, with an air speed lower than $0.2 \mathrm{~m} / \mathrm{s}$ to prevent evaporation and subsequent skin thermal loss by forced convection, seated or standing, when possible, without clothes on the upper and lower body parts (only underwear), for the stabilization of the cutaneous body temperature.

Long hair was tied back to avoid image interference. During the period in which they were sat or remained standing, the patient was not allowed to touching his/her trunk with the hands or any other surface.

Subsequently, by infrared images of anterior, lateral, posterior and oblique incidences were obtained, horizontally positioning the infrared camera at a 1 meter distance and vertically adjusted in horizontal line with the patient's body.

The IR images were captured by the infrared sensor of $160 \times$ 120 resolution with $20^{\circ}$ lenses. The thermal sensitivity employed was $0.1^{\circ} \mathrm{C}$ by color shade, using a rain-type colorimetric scale (palette). The colors are, from warmer to colder, white, pink, red, orange, yellow, light green, dark green, light blue, dark blue, purple and black, directly indicating the distribution level of local cutaneous blood perfusion. All images were exposed with the palette side by side for consulting reasons, when comparable within the same upper and lower temperature thresholds.

Pain and intolerance to cold were quantified through analogical visual scales (AVS).

\section{Statistical analysis}

Data were analyzed comparing the average temperature values in TO and T4, looking for a evidence of MIG3 fabrics use. The bimodal pared t-test was used for an $\alpha$ error of 0.05. There were also evaluated the AVS values and polysomnographic parameters before and after the use of MIG3 fabrics using respectively chisquared test and pared t-test (considering $\mathrm{p}<0.05$ and $\alpha=0.05$ ). 
Table 2. Sleep quality.

\begin{tabular}{|c|c|c|c|}
\hline Polisomnographic parameters & $\begin{array}{l}\text { Pre-treatment night } \\
\qquad \begin{array}{c}N=12 \\
\text { Mean } \pm S D\end{array}\end{array}$ & $\begin{array}{l}\text { Post-treatment night } \\
\qquad \begin{array}{c}\mathrm{N}=12 \\
\text { Mean } \pm \mathrm{SD}\end{array}\end{array}$ & $\begin{array}{c}\text { T-test } \\
\mathrm{p}\end{array}$ \\
\hline Sleep efficiency, \% & $72 \pm 14.0$ & $72.6 \pm 8.9$ & NS \\
\hline REM latency, min & $130 \pm 89$ & $161 \pm 99$ & NS \\
\hline Stage 1, \% & $4.3 \pm 2.9$ & $5.7 \pm 4.3$ & NS \\
\hline Stage 2, \% & $66.6 \pm 12.1$ & $62.2 \pm 13.3$ & NS \\
\hline Stage 3, \% & $2.1 \pm 2.2$ & $3.8 \pm 2.5$ & $p<0.05$ \\
\hline Stage $4, \%$ & $8.4 \pm 8.6$ & $11.9 \pm 7.8$ & NS \\
\hline REM sleep, \% & $16.3 \pm 8.3$ & $19 \pm 6.7$ & $p<0.05$ \\
\hline Arousal index, $\mathrm{n} / \mathrm{h}$ & $13.0 \pm 10$ & $11.8 \pm 7.8$ & NS \\
\hline TTS, min & $331 \pm 75$ & $324.5 \pm 53.6$ & NS \\
\hline Sleep latency, min & $48.0 \pm 40$ & $32.3 \pm 19.3$ & NS \\
\hline PLM index, $\mathrm{n} / \mathrm{h}$ & $11 \pm 14.0$ & $3.7 \pm 6.3$ & $\mathrm{P}<0.05$ \\
\hline RR awake, bpm & $18 \pm 3$ & $14.7 \pm 2.6$ & NS \\
\hline RR REM, bpm & $15 \pm 4$ & $15.2 \pm 3.4$ & NS \\
\hline RR NREM, bpm & $22 \pm 18$ & $15.5 \pm 3$ & NS \\
\hline HR NREM, bpm & $77 \pm 14$ & $66 \pm 11$ & $p<0.05$ \\
\hline HR REM, bpm & $75 \pm 14$ & $66.7 \pm 10.4$ & $p<0.05$ \\
\hline HR awake, bpm & $83 \pm 17$ & $72.2 \pm 10.8$ & $\mathrm{p}<0.05$ \\
\hline
\end{tabular}

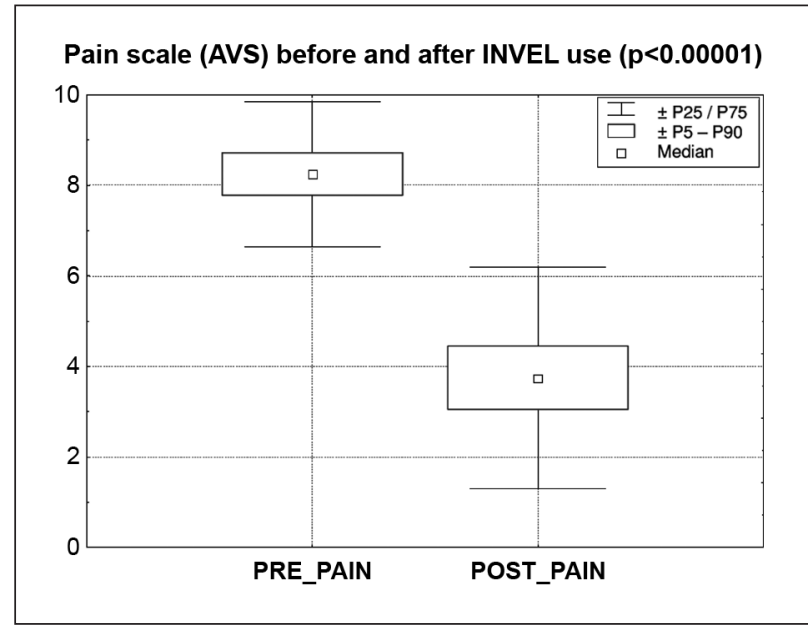

Fig 1. Pain visual analogical scale.

\section{RESULTS}

We found a significant decrease in pain intensity $(8.3 \pm 2.5$ vs. 3.8 \pm 2.5$)$. A slight non-significant decrease in intolerance to cold was also observed ( $6.4 \pm 2.3$ vs. $5.3 \pm 2.4$ ) (Fig 2).

The polysomnographic exam demonstrated a significant decrease in the PLM index (11 \pm 14 vs. $3.7 \pm 6.3$ ), a significant decrease in the heart rate (HR) during wake $(83 \pm 17 \mathrm{vs}$. $72.2 \pm 10.8)$, REM sleep ( $75 \pm 14$ vs. $66.7 \pm 10.4)$ and non-REM

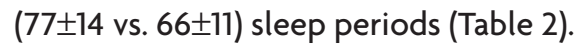

The infrared exam did not show a significant decrease in the subcutaneous temperature range after the use of fabrics with MIG3 bioceramics; however, there was an improvement in intolerance to cold clues and complaints of pain (Fig 2).

\section{DISCUSSION}

The radiation emitted by long infrared (LIR) fabrics increases membrane permeability and the calcium concentration in the cell membrane and cytoplasm; it biologically stimulates the cell, favoring the exchange of metabolites within the extracellular medium, nurturing the cell. It also acts on mitochondria, promoting the ATP synthesis used in muscular contraction ${ }^{16}$.

The muscle-skeletal system is also benefited by the effects of LIR, so that its application promotes a decrease in muscle spasms, as well as muscle relaxation. The metabolic rate may suffer an increase of about $13 \%$ for each rise of $1^{\circ} \mathrm{C}$ in the tissue temperature, and the increase in metabolism will be higher in the region where most of the heat is generated. As a result of this, there is a high tissue demand for oxygen and nutrients, resulting in an increase in the catabolic products clearance ${ }^{17}$ and in stimulation for substance release, such as endorphins and endocephalines which are provided with analgesic properties similar to those of morphine ${ }^{18}$. Due to these analgesic properties of MIG3 bioceramics, long infrared emitter, 

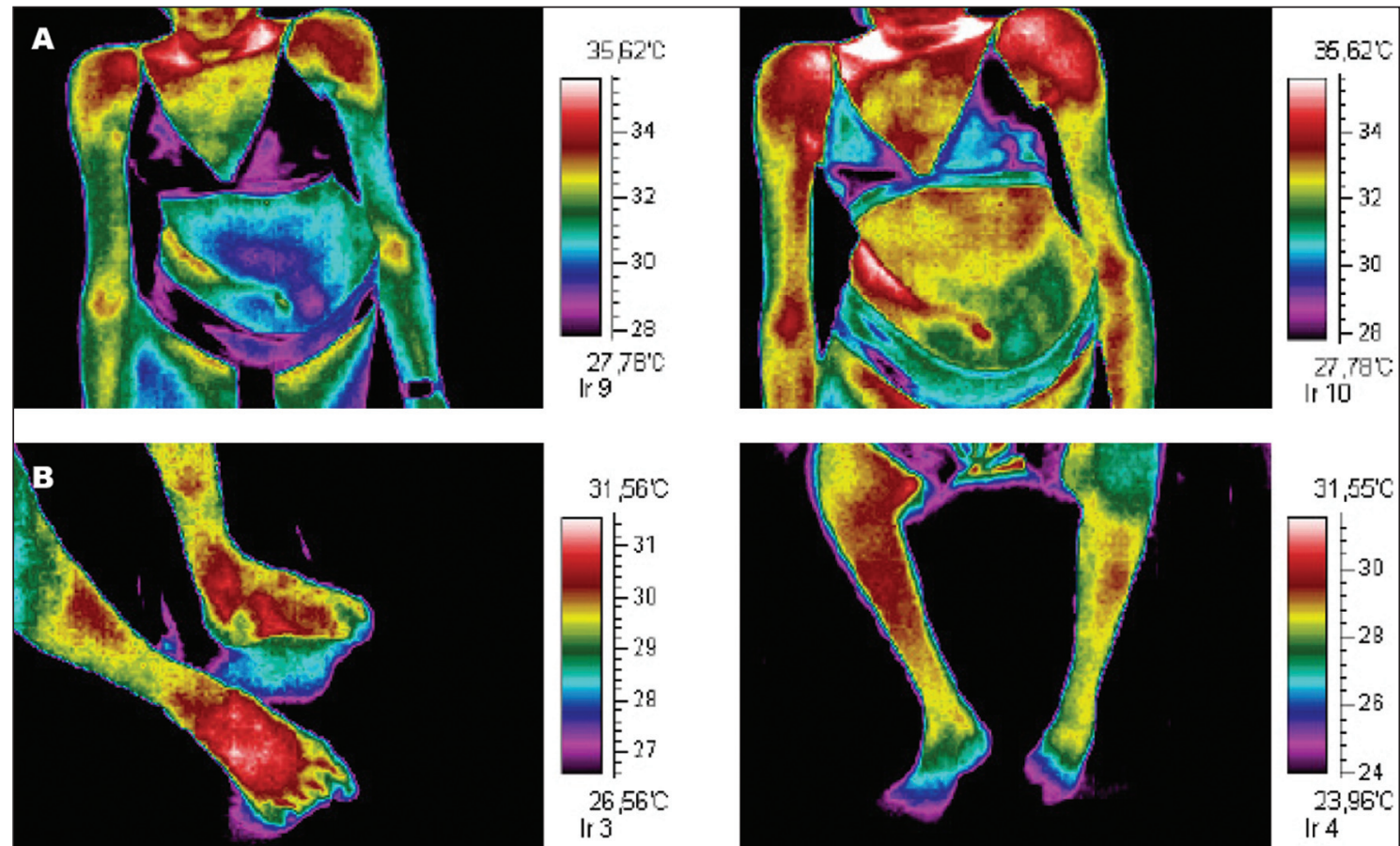

Fig 2. Adjustment of subcutaneous temperature after the use of fabrics with MIG3 bioceramics. [A] increase in the subcutaneous temperature in the trunk area; $[B]$ decrease in the subcutaneous temperature of the feet and legs.

the significant improvement in pain complaints can be explained in patients assessed.

The main effects of long infrared include improved circulation, increased immunity, repair and regeneration of tissues and the regulation of body fluids (humoral system). The rise in body temperature and increased mobility of body fluids ${ }^{14}$, in addition to pain relief, are also some consequences of $\operatorname{LIR}^{15}$. A significant improvement of intolerance to cold was expected in patients with PPS due to enhanced circulation, but this improvement may not reached due to peripheral muscle atrophy, but also to impairment in the body temperature regulatory centers of the central nervous system.

This study demonstrated that the use of fabrics impregnated with MIG3 bioceramics, when in contact with the skin during the sleep period, can alter sleep quality.

We found that there was a significant improvement in PLM and HR indexes during periods of wakefulness, REM and NREM sleep after a month of use of mattresses fitted with MIG3 bioceramics.

The most accepted cause for the occurrence of PLM is that there is a change in the production of dopamine, provoked by iron deficiency. Patients with PPP have a PLM index higher than the general population and in a higher frequency, perhaps due to injury of neurons in the brainstem or even of the motor neurons in the anterior horn of the spinal cord.
The MIG3 bioceramics in contact with the skin is known to produce a vasodilatation of arteries that irrigate the skin and muscles, facilitating the venous return, and reducing the cardiac pre-load. This goes some way towards explaining the significant decrease in the heart rate before and after the use of fabrics impregnated with MIG3 bioceramics.

Studies performed in 1988 with the use of LIR showed improvement in the quality of sleep in patients and rats ${ }^{12}$. In 1995, studies confirmed that LIR therapy lead to an improvement in the quality of life, quality of sleep and general well-being of patients with chronic fatigue syndrome $^{13}$. These factors may result from the increase in the brain temperature associated with the type of neuronal activation, characteristic of sleep in the hypothalamus and brainstem. The central nervous system excitation is reduced by increasing the blood temperature in the hypothalamus; resulting in a somniferous effect. The improvement in the symptoms is believed to be caused by the reduction in pain and improvement in sleep ${ }^{13}$.

To conclude, the use of fabrics and mattresses fitted with MIG3 bioceramics, a long infrared emitter, over four weeks, had significantly reduced complaints of pain and improved sleep quality. There was also a significant reduction in PLM and heart rate indexes. Future studies should aim at enhancing our current data base on this exciting research area. 


\section{REFERENCES}

1. Oliveira ASB, Maynard FM. Síndrome pós-poliomielite: aspectos neurológicos. São Paulo: Rev Neurociências 2002;10:31-34.

2. Dalakas MC. Post-polio syndrome 12 years later. In: The post-polio syndrome: advances in the pathogenesis and treatment. Ann NY Acad Sci 1995;753:11-18

3. Halstead LS. Managing post-polio: a guide to living well with post-polio syndrome. Arlington VA. ABI Professional Publications, 1998.

4. Mulder DW. Post-polio syndrome: Past, present and future. In: Munsat TL (Ed). Post-polio syndrome: past, present and future. Boston: Butterworth-Heinemann, 1991:1-8.

5. Maynard FM, Headley JI. Manual acerca dos efeitos tardios da poliomielite, para médicos e sobreviventes. Associação Pós-Pólio de Portugal. Col "Rumos e Perspectivas", 2000:1.

6. Martins PJF, Mello MT, Tufik S. Exercício e sono. Rev Bras Méd Esporte 2001:7;28-36.

7. Martinez D. Prática da medicina do sono. BYK 1999;1:276.

8. Montplaisir J, Laverdière M, Saint-Hilaire JM. Sleep and epilepsy: long term monitoring in epilepsy. EEG 1985:37(Suppl):S215-S239.

9. O'keeffe ST. Restless legs syndrome: a review. Arch Med Intern 1996: $156 ; 243-248$
10. Ekbom KA. Restless legs syndrome. Neurology 1960:10;868-873.

11. Masuko AH, Prado LBF, Prado GF. Síndrome das pernas inquietas. Rev Neurociências 2004;12:18-20.

12. Honda K, Inoué S. Sleep-enhancing effects of far-infrared radiation in rats. Int J Biometeorol 1988;32:92-94.

13. Masuda A, Kihara T, Fukudome T, Shinsato T, Minagoe S, Tei C. The effects of repeated thermal therapy for two patients with chronic fatigue syndrome. J Psychosomatic Res 2005;58:383-387.

14. Inoue $\mathrm{S}$ E, Kabaya M. Biological activities caused by far-infrared radiation. Int J Biometeorol 1989;33:145-150.

15. Massayoshi Y, Takashi T. Far infrared- results and treatments for cancer. Tokyo Joshi Ika Daigaku Medical University. Ed. Toppan Insatsu Kabushiki-Kaisha-Tokyo, 1989.

16. Toyokawa H, Matsui Y, Uhara J, et al. Promotive effects of far-infrared ray on full-thickness skin wound healing in rats. Exp Biol Med 2003; 228:724-729.

17. Kitchen S, Bazin S. Eletroterapia de Clayton. $10^{a}$ edição. São Paulo: Manole, 1998.

18. Junqueira LC, Carneiro J. Histologia Básica. 8.Ed. Rio de Janeiro: Guanabara Koogan, 1995 